\title{
Measurement of trypsin and chymotrypsin activity in stools to detect chronic pancreatic disease
}

\author{
J. G. BANWELL ${ }^{1}$, P. J. LEONARD ${ }^{2}$, AND RITA M. F. LOBO \\ From the Department of Medicine, Makerere University College, Kampala, Uganda
}

EDITORIAL SYNOPSIS Trypsin and chymotrypsin activity per gram of stool varies inversely with the weight of the sample in control African subjects. The total daily output of both enzymes in patients with pancreatic calcification does not differ significantly from the output of control subjects. The lower mean concentration of the enzymes in chronic pancreatic disease can be accounted for by the weightier stool found in these patients.

Pancreatic calcification is found amongst the indigenous African community in Uganda (Shaper, 1960) and pancreatic exocrine failure has been shown to be the major cause of the malabsorption syndrome in these people (Banwell, Campbell, Blackman, Hutt, and Leonard, 1963). The incidence of chronic pancreatic disease in this population is unknown and the gastroenterological techniques at present available to assess the prevalence of the condition are unsuitable for large surveys.

Haverback, Dyce, Gutentag, and Montgomery (1963) introduced a new method for measuring trypsin and chymotrypsin levels in faeces. The substrates employed are specific for trypsin and chymotrypsin and they suggested that this method would accurately measure the enzyme level in the stool, so that by the analysis of a spot stool sample the method could be applied as a screening test for the diagnosis of chronic pancreatic disease. The present study was undertaken to see if the method could be used to determine the incidence of chronic pancreatic disease in an African community.

\section{MATERIALS AND METHODS}

Total 24-hour or spot stool samples were collected in waxed cardboard cartons from the following subjects admitted to the wards of Mulago Hospital, Kampala, Uganda:-

1 One hundred and three subjects with diseases unrelated to the gastrointestinal tract such as hypertension, pneumonia, and congestive cardiac failure. These were used as controls. 2 Ten subjects with pancreatic calcification as shown by radiography of the upper

\footnotetext{
${ }^{1}$ Present address: The General Hospital, Birmingham 4 ${ }^{2}$ Supported by a grant from the Tropical Medicine Research Board (M.R.C.)
}

abdomen. All subjects were diabetic and had steatorrhoea. Secretin-pancreozymin tests (Burton, Evans, Harper, Howat, Oleesky, Scott, and Varley, 1960) performed on eight of these subjects revealed grossly impaired secretory function. 3 Nine subjects with diabetes mellitus but without evidence of pancreatic exocrine insufficiency. 4 Four subjects with severe protein calorie malnutrition. 5 Six subjects with hepatic cirrhosis.

All specimens were stored at $-15^{\circ} \mathrm{C}$. immediately after collection and were analysed within three weeks of collection. No change in enzyme activity was noted during the period of storage. This was checked by analysing an aliquot of homogenized stool at daily intervals for seven days and again on the fourteenth and twenty-first days.

The method used was essentially the same as that described by Haverback et al. (1963). All determinations were carried out at room temperature $\left(25^{\circ} \mathrm{C} . \pm 1^{\circ} \mathrm{C}\right.$.). An automatic titrator was not available for our studies but experiments conducted with an E.I.L. $p \mathrm{H}$ meter and a stop watch showed that highly reproducible results could be obtained with standard solutions which contained more than $20 \mu \mathrm{g}$. of the enzymes per millilitre. Adequate mixing was ensured by the use of a magnetic stirrer. All stool samples were homogenized and diluted so that the enzyme level was between 20 and $40 \mu \mathrm{g}$. in each sample to be analysed.

\section{RESULTS}

The mean results ( \pm standard error) obtained in the various groups are presented in Table I. The total daily output of trypsin and chymotrypsin did not differ significantly from the levels found in control subjects in either the group with pancreatic calcification or those with diabetes mellitus without exocrine deficiency. Analysis of spot stool samples revealed that the values obtained for both enzymes (mg./g.) were significantly lower $(\mathrm{P}<0.05)$ in the group with 
TABLE I

STOOL TRYPSIN AND CHYMOTRYPSIN LEVELS IN EAST AFRICAN SUBJECTS

\begin{tabular}{|c|c|c|c|c|c|c|}
\hline \multirow[t]{2}{*}{ Subjects } & \multirow{2}{*}{$\begin{array}{l}\text { No. of } \\
\text { Subjects }\end{array}$} & \multicolumn{2}{|c|}{ Daily Output (mg.) } & \multirow{2}{*}{$\begin{array}{l}\text { No. of } \\
\text { Subjects }\end{array}$} & \multicolumn{2}{|c|}{ Spot Stool (mg./g.) } \\
\hline & & Trypsin & Chymotrypsin & & Trypsin & Chymotrypsin \\
\hline Control & 54 & $\begin{array}{r}282 \\
+\quad 11.8\end{array}$ & $\begin{array}{r}20.8 \\
+\quad 0.75\end{array}$ & 49 & $\begin{array}{r}4.54 \\
+0.64\end{array}$ & $\begin{array}{r}0.350 \\
+0.05\end{array}$ \\
\hline Pancreatic calcification & 10 & $\begin{array}{r}269 \\
+\quad 45.4\end{array}$ & $\begin{array}{r}16.9 \\
+\quad 2.78\end{array}$ & 5 & $\begin{array}{l}1.96^{1} \\
\pm 0.53\end{array}$ & $\begin{aligned} & 0.143^{1} \\
\pm & 0.05\end{aligned}$ \\
\hline Diabetic, non-pancreatic & 8 & $\begin{array}{l}289 \\
\pm 22.4\end{array}$ & $\begin{array}{r}20.1 \\
\pm \quad 1.26\end{array}$ & 5 & $\begin{array}{r}3.58 \\
\pm 0.75\end{array}$ & $\begin{array}{l}0.303 \\
\pm 0.07\end{array}$ \\
\hline Hepatic cirrhosis & & & & 6 & $\begin{array}{r}4.20 \\
+1.08\end{array}$ & $\begin{array}{r}0.305 \\
+0.10\end{array}$ \\
\hline Malnourished adult & & & & 4 & $\begin{array}{r}6 \cdot 12 \\
\pm 2 \cdot 25\end{array}$ & $\begin{array}{l}0.388 \\
\pm 0.05\end{array}$ \\
\hline
\end{tabular}

pancreatic calcification than in the control group. The mean values obtained in the other groups studied were not significantly different from the control series.

The range of values found per gram of spot stool in the five subjects with chronic pancreatic disease was 0.39 to $3.33 \mathrm{mg}$./g. for trypsin and 0.034 to $0.255 \mathrm{mg}$./g. for chymotrypsin. Twenty-seven of the 49 control subjects had trypsin values within this range and 29 were within the chymotrypsin range. Two subjects in the control group had the lowest recorded values for chymotrypsin. Twelve control subjects had trypsin levels per gram of stool below the mean value in the group with pancreatic calcification and 14 had levels below the mean chymotrypsin value.

\section{DISCUSSION}

Haverback et al. (1963) showed that the trypsin and chymotrypsin level per gram of spot stool was lower in patients with chronic pancreatic disease than in control subjects. This finding was confirmed in the present study but the total daily output did not differ significantly from that found in control subjects. In a previous study, the mean daily output of stool in subjects with chronic pancreatic disease was shown to be higher than in a control group (Banwell et al., 1963). When the relationship between weight of spot stool specimen and the enzyme activity per gram weight of stool was examined in the 49 control subjects of this series (Table II) increased weight of stool was found to be associated with a reciprocal decrease in faecal trypsin and chymotrypsin activity. Enzyme activity was significantly lower $(p=0.05)$ in spot samples over $120 \mathrm{~g}$. weight. Moreover, the mean activities found in the 10 control subjects whose spot stool weight exceeded $120 \mathrm{~g}$. were almost identical with those observed in the pancreatic calcification group. This finding may explain the lower mean enzyme activity in the pancreatic subjects whose stool weights could be expected to be higher

\section{TABLE II}

RELATIONSHIP BETWEEN ENZYME ACTIVITY PER GRAM OF SPOT STOOL (MEAN \pm S.E.) AND TOTAL WEIGHT OF STOOL SAMPLE IN CONTROL SUBJECTS

\begin{tabular}{|c|c|c|c|c|}
\hline Group & $\begin{array}{l}\text { No. of } \\
\text { Subjects }\end{array}$ & $\begin{array}{l}\text { Range of Spot } \\
\text { Stool Weight (g.) }\end{array}$ & $\begin{array}{l}\text { Trypsin } \\
(m g . / g .)\end{array}$ & $\begin{array}{l}\text { Chymotrypsin } \\
\text { (mg./g.) }\end{array}$ \\
\hline I & 30 & $<40$ & $\begin{array}{r}5.60 \\
\pm 0.90\end{array}$ & $\begin{array}{l}0.460 \\
\pm 0.08\end{array}$ \\
\hline II & 9 & $40-120$ & $\begin{array}{r}4.08 \\
+1.13\end{array}$ & $\begin{array}{c}0.248 \\
\pm 0.05\end{array}$ \\
\hline III & 10 & $>120$ & $\begin{array}{r}1.79^{1} \\
\pm 0.30\end{array}$ & $\begin{array}{c}0.148^{1} \\
\pm 0.02\end{array}$ \\
\hline
\end{tabular}

on the average than those of control subjects in this series.

The mean chymotrypsin value per gram of stool in our control subjects was practically identical with that found in a similar group of subjects studied by Haverback et al. in North America (1963), being $0.350 \mathrm{mg} . / \mathrm{g}$. in the present study and $0.340 \mathrm{mg} . / \mathrm{g}$. in the latter study. The mean trypsin value, however, was very much higher in those studied here, being $4.54 \mathrm{mg}$./g. compared with a value of $0.104 \mathrm{mg}$./g. in the study of Haverback et al. (1963). This large difference in trypsin activity may be due to the different dietary and bowel habits of the two groups. The staple diet of the indigenous African population is vegetarian, consisting of steamed banana or cassava with various vegetable and meat stews added as relish. Food is usually taken in large quantities twice daily. Such a diet is high in fibre content and produces a bulky faecal residue which is evacuated two or three times a day as a soft, formed stool (Trowell, 1960). It is probable that the intestinal transit time and turnover rate of faeces in the colon is increased under these dietary conditions in comparison with subjects on a North American diet. Crawford (1964) has even suggested that the high serotonin content of the banana may increase intestinal motility. Others have doubted this (Connell, Rowlands, and Wilcox, 1960). Wohlman, Kabacoff, and Avakian (1962) have shown that 
trypsin is much less stable than chymotrypsin in human intestinal juice. Thirty minutes after the addition of these enzymes to human intestinal juice, $63 \%$ of the chymotryptic activity and only $8 \%$ of the tryptic activity remained. Thus even a small increase in the intestinal transit time might result in a large increase in the stool trypsin level due to the shorter period of exposure to the inactivating effect of the small intestinal and colonic environment. The technique used in this study is time consuming and expensive and would be difficult to apply in a laboratory on a modest budget as a screening procedure to detect pancreatic disease.

\section{SUMMARY}

Trypsin and chymotrypsin activities in faeces were measured in African subjects by the method of Haverback et al. (1963). The total daily output of both enzymes in patients with pancreatic calcification did not differ significantly from the values found in control subjects. The mean activity of trypsin and chymotrypsin per gram in spot stool was significantly lower in subjects with chronic pancreatic disease. This difference was probably due to the larger stool weights which are to be expected in such patients. The enzyme content per gram in spot stool was inversely related to the weight of the sample in control subjects. Owing to the wide scatter of the results in the control group and the dependence of the results on the weight of the spot stool sample, it was concluded that this technique was unsatisfactory for the detection of chronic pancreatic disease in the population we studied.

We wish to thank Professor J. A. Tulloch for his help and encouragement and the East African Medical Research Council for a grant towards the expenses of the study.

\section{REFERENCES}

Banwell, J. G., Campbell, J., Blackman, V., Hutt, M. V., and Leonard, P. (1963). Studies of intestinal function in Ugandan diabetic patients. $E$. Afr. med. J., 40, 277-287.

Burton, P., Evans, D. G., Harper, A. A., Howat, H. T., Oleesky, S., Scott, J. E., and Varley, H. (1960). A test of pancreatic function in man based on the analysis of duodenal contents after administration of secretin and pancreozymin. Gut, 1, 111-124.

Connell, A. M., Rowlands, E. N., and Wilcox, P. B. (1960). Serotonin, bananas, and diarrhoea. Gut, 1, 44-47.

Crawford, M. A. (1964). Degradation of amino-acids in the large gut of East Africans and its possible significance. E. Afr. med.J., 41, 228-238.

Haverback, B. J., Dyce, B. J., Gutentag, P. J., and Montgomery, D. W. (1963). Measurement of trypsin and chymotrypsin in stool: a diagnostic test for pancreatic exocrine insufficiency. Gastroenterology, 44, 588-597.

Shaper, A. G. (1960). Chronic pancreatic disease and protein malnutrition. Lancet, 1, 1223-1224.

Trowell, H. C. (1960). Non-infective Disease in Africa, p. 217. Edward Arnold, London.

Wohlman, A., Kabacoff, B. L., and Avakian, S. (1962). Comparative stability of trypsin and chymotrypsin in human intestinal juice. Proc. Soc. exp. Biol. (N.Y.), 109, 26-28. 